\title{
Neoliberal Discourse in Italy and European Integration: The Jobs Act and the Pensions Reform
}

\author{
By Luca Bifulco*
}

\begin{abstract}
The paper aims to analyze how in Italy - as in the European Union - the neoliberal discourse tries to create consent on certain social, political and economic assumptions. Analysing the public discourse of Italian governments related to the Jobs Act (2014-15) and the pensions reform (2011), the paper underlines their neoliberal inspiration and the attempt to build common sense on competitiveness, economic growth, free market, deregulation, social spending, debt sustainability, austerity, employment, supporting a notion of general interest and social priority. But ideas are never neutral, and they could legitimize inequalities and the power of dominant classes.
\end{abstract}

Keywords: discourse, Jobs Act, Neoliberalism, Pensions reform power.

\section{Introduction}

Many times we hear phrases like: only free market and labour flexibility create jobs; the public spending is excessive and reduces economic growth and, consequently, employment; the State cannot afford pensions, and austerity and debt sustainability are necessary to welfare; etc. Experts, politicians and ordinary people often share these common ideas.

But ideas and theories are never neutral, they can be a guide to solve problems, but they can be also a point of view supporting social and power relationships. That is a means to legitimise a world order, even its inequalities.

In the last years, the economic measures adopted in Europe were often inspired by neoliberal doctrines. At the same time, these policies have been supported by a public discourse that tried to incorporate these ideas within the common sense and a notion of general interest.

This paper evaluates the public statements, official documents and communication of members of Italian government during the period before the approval of two crucial reforms: the Jobs Act - 2014-15 - and the pension reform - 2011. This in order to underline their ideological inspiration and the implicit attempt, in the discursive struggle, to shape and spread a "neoliberal common sense".

\footnotetext{
* Luca Bifulco, Assistant Professor, Università degli Studi di Napoli Federico II, Dipartimento di Scienze Sociali, Italy.
} 


\section{Theoretical Framework: Discourse, Ideology and Power}

Ideas, material productive relations and social actions are always connected. For Robert Cox, material capabilities, ideas and institutions are the forces interacting in what he calls the "framework for action" - or "historical structure" (Cox 1981: 135-138). Their composition doesn't mechanically shape actions, but "imposes pressures and constraints. Individuals and groups may move with the pressures or resist and oppose them, but they cannot ignore them. To the extent they do successfully resist a prevailing historical structure, they buttress their actions with an alternative, emerging configuration of forces, a rival structure. (...) No one-way determinism need be assumed among these three; the relationship can be assumed to be reciprocal. The question of which way the lines of force run is always a historical question to be answered by a study of the particular case" (Cox 1981: 135-136).

Material capabilities are the productive factors, such as technology, organizational factors, resources, etc. The ideas are composed of intersubjective meanings - that is "shared notions of the nature of social relations which tend to perpetuate habits and expectations of behaviour" - and collective images of social order that the different groups own, which include the general moral ideas - the public good, equality, etc. - and the opinions about the power and its legitimacy. There's always a conflict among different collective images - and groups holding them - so that alternative structures can emerge. Institutions are the instrument to establish and perpetuate a social order - although in some cases they may be factors of transformation.

Social reality is always made up of many groups with different interests, ideas, resources. The unequal access to resources - material, political, symbolic - seems to be an inescapable feature of every society. Thus, inequality, stratification, conflict are always present.

The conflict among groups - or also social forces, and classes, obviously is always material and ideological. Ideologies are fundamental systems of beliefs, values, viewpoints, knowledge and representations shared by members of groups. Every ideology is never neutral, but it always prescribes a direction that benefits someone. And power at any level - even the coercive power of State agencies - is more effective if ideologically complemented.

When Charles Tilly tries to understand why subordinate groups comply and don't revolt or resist incessantly, he provides different explanations: they can get something in return, maybe they haven't enough means to rebel, or they agree with a worldview - internalized - because they have no strong alternative ideas (Tilly 1991: 594). Obviously these explanations can be combined, but - in any case - the role of ideas and consent remains essential.

Actually, people understand, interpret actions and relationships in which they are involved. And the way in which people give meaning to the social world affects in turn their actions and interactions.

The ideas inspire the way in which people and groups realize their social conditions and the opportunity to change (Gill and Law 1998: 71-76), and at 
the same time they could be used as a means to legitimise specific policies, social conditions, power relations (Bieler 2001).

This is the reason why the power of dominant groups has always both material and ideological basis, and the discourse - that conveys the meanings underpinning economical and social reality - has a crucial rule.

"Discourse" is a composite concept. I mean, most of all, texts and talks producing and conveying knowledge, points of view, opinions. Through language the discourse shapes social relations, being a basis on which thoughts, interactions and actions are founded (Purvis and Hunt 1993: 485).

Most of all when organized and institutionalized - in the scientific community, in political or economic institutions, etc. - the discourse proposes beliefs, thoughts or knowledge systems and codes, that disengage themselves from the single talker and are the resources through which we can give meaning to reality and navigate in the world, configuring our relationships and behaviours. The discourse circumscribes and regulates experiences and meanings, influencing or preventing what is said or done.

Thus, the discourse creates collective identities and political subjectivities, and it can be intertwined with ideology. Ideology inspires the discourse and is, in turn, produced and reproduced in the discourse - although a discourse is not always ideological.

If the discourse can be an ideological weapon, it is because it can be tied to a system of domination, presenting partisan interests as general interests in order to incorporate them in common lived experience (Purvis and Hunt 1993: 496-498). Social relations can be presented as universal and inevitable, so that interests are considered natural and universal too.

Discourses are, thus, sites in which power is produced and can grow although they can also convey forms of resistance. As mentioned before, power, in fact, is shaped not only by material coercion, but also by the production, organization and circulation of knowledge and meanings. For this reason discourse and discursive practices are decisive.

Social power can be founded on specific discursive aspects: who has the right to talk about a specific topic, what are the forms and methods of knowledge defining the "truth", the ideas and the beliefs circulating, but also what is not said, what is not in the interpretive framework.

In texts, in speeches, in talks, members of social groups can produce or reproduce the relationships and the strategies of power, dominion, inequality as well as contentious reactions. Thus, power, dominion and inequality can be enacted and confirmed in the discourse. Elites have greater control of the most relevant and widespread discourse genres and they can more easily regulate the discursive contexts. Actually, they have a preferential access to the public and institutional forms of speeches, texts, talks - media communication, institutional and scientific discourse, etc.

This discursive dominion, the control of the contexts where discourses are produced and reproduced and where ideas are conveyed, and consequently the greater ability to regulate contents and meanings, gives the dominant groups the opportunity to safeguard their own interests. 
Controlling the production of the most visible meanings and knowledge, but also who is allowed to speak on a particular topic, means affecting the interpretation and the understanding of reality. For this reason regulating discourses and their features is a direct enactment of social and institutional power.

If discourses define knowledge, beliefs and ideas, affecting opinions, attitudes and actions, the recipients are, of course, not entirely passive. They can resist and bear in mind their interests and interpretations. Nevertheless, forms of persuasion and influence - by the dominant groups - can be strong, since members of subordinate groups may have few alternatives, counteropinions or counter-ideologies, as well as a little knowledge about communicative strategies.

Not surprisingly, in the gramscian - and neo-gramscian - view the power of a dominant class and its representatives is based on the combination of coercion and persuasion - or consent (Gramsci 1975). Its attempts to be hegemonic are built on the consistent union of the material supremacy, the common idea of world order and the institutions administrating this order apparently on universal principles (Cox 1981: 139).

Power is so a relation based on the organization of consent, and a dominant class - or class fraction - in the political and ideological arena/conflict must achieve the consent of other social forces and classes, producing and preserving bonds with them through some economic accommodations - which are relevant - but also an ideological apparatus suggesting the persistence of reciprocal interests.

As Cox says, power means bringing "the interest of the leading class into harmony with those of subordinate classes and incorporates these other interests into an ideology expressed in universal terms" (Cox 1983: 168). As we have seen, civil society - including academy and media - has a fundamental function, since it is able to legitimise and reproduce ideologies and shared meanings by supposed universal arguments.

All this means that it is necessary that subordinate classes agree to a worldview, taken as universal. If it becomes common sense, it legitimizes in the strongest way the social relations and the political order in which they are subordinate. As a matter of fact, when knowledge, ideas and beliefs become common sense, individuals more easily accept values and norms of a system potentially exploiting them. The most radical version of power, presumably, is not visible (Lukes 2005).

As conflict sociology has highlighted (Collins 1992: 72-75) power ultimately lies on the ability to focus on certain aspects of social reality, thus controlling what is taken for granted. This means building a wide area of implicit agreement, which can also accommodate some disputes. Thus, inequality can be reinforced by discourses conveying a truth that is taken for granted and accepted by so many persons belonging to different social classes, which incorporate these meanings in their daily knowledge and experience.

Common sense, which is spontaneous and unaware, is an uncritical conception of the world and it is the place in which ideology and power are 
built and increase - even if it could be at the same time the place where an alternative for resistance can by constructed, since the political context is always characterized by material, ideological struggles and competing interests and ideologies.

This is why a hegemonic effort must be continuously reshaped, through discourse, by virtue of the contingencies and of the constant negotiations among the social forces.

\section{The Political Background: European Integration and Neoliberal Paradigm}

The process of European integration has been an economic and strategic project characterized by a conflict among social forces and has generated a new European socio-economic order. Its dynamics in the last decades, as emphasized most of all by many neo-gramscian studies, seem to correspond to the neoliberal discourse (Overbeek 2004).

The Treaties that shaped the European Union - Maastricht in 1992 and Lisbon in 2008 - have produced a specific political order. Unelected institutions (the European Commission, the European Council and the European Central Bank) decide and inspire, almost independently and with a few restrictions, the economic and social policies that are prescribed to the Member States. And the monetary policy is ever more managed by independent central banks. The International Monetary Fund, which has no official duties in the European Union, has instead a clear political weight. Finally, the agenda of economic and social policy is strongly influenced by large financial, banking and industrial groups. It means a composite transnational governance model involving States and non-State actors (Van der Pijl 1989).

All these share a neoliberal notion of European integration. The basic idea of the neoliberal paradigm is that the expansion of free market automatically fosters economic growth and employment ensuring broad social wellbeing. The State must ensure the freedom of individuals and companies, which can act without constraints. Deregulation, namely the lack of barriers imposed by the State, the privatization of more and more economic sectors and the competition enhance productivity and efficiency, lowering prices, controlling inflation, and therefore increasing wealth for everybody and improving the quality of life. According to this view only free trade and markets can reduce poverty (Harvey 2005: 64-67).

At the same time, Europe should take advantage of the positive and autonomous forces of globalisation and world free trade. This perspective sees the market as the way out of the crisis against the encrusted and rigid labour and welfare obligations. Thus, the functioning of markets and the financial system is the main concern of the European institutions and oligarchy. In addition, in the Treaties it is clear the plan to preserve first of all the market competitiveness, when less attention is paid to the idea of full employment, 
while the ECB is committed to fight inflation and to supervise the European public budgets.

The political activation of national European governments in the last decades has been loyal to the orthodoxy of market, fiscal and monetary strategies which are considered useful to increase the credibility of the single States in the eyes of financial market actors. Investors, first of all, look for low inflation and stability of the value of money, and the favoured ways to reach this target are the central bank independence and the national depoliticization of the issues related to money and finance - to separate the economic, financial, fiscal decisions from the pressures of national social instances. At the same time the budget deficits of States must be sustainable to reduce the risk of default and guarantee investors and bondholders - public services cuts and privatizations are considered more practicable policies than higher taxes that may cause excessive and explicit discontent (Gill 2001: 58-59).

Thus, in the last years, the austerity policies required in many States by the so-called Troika - IMF, European Commission, ECB - have imposed financial stability and reforms to make severe budget rules, supported by the idea that the excessive public spending of the States is the cause of the contemporary economic crisis. The European Stability Mechanism - an intergovernmental organization that can lend money to Member States in financial difficulty in return of stringent measures to restore financial stability - and the Fiscal Compact - a treaty that requires the tightening of financial and budget rules are two clear examples of this political strategy.

National governments, whose dynamics are connected to inter-state and world order and whose internal consent is linked to the global ideological common framework (Cox 1987), are asked to reduce their spending for public services, to implement reforms that lower the cost of labour and reduce workers' rights.

This is the way - the neoliberal orthodoxy stresses - to the economic recovery.

Furthermore, the State guarantees the freedom of people and market, and this means, for the neoliberal paradigm, that each person individually builds his/her wealth and is responsible for it. Even fields generally guaranteed by the social protection - pensions, unemployment and so on - are considered as areas in which the individual autonomously acts and chooses, taking charge of the failures or successes, while the State should only provide useful tools to acquire skills and make the best choices (Harvey 2005: 65-66).

Media, academics and experts have a central role disseminating these ideas and transforming them into universal and unquestionable view on the social order, even for the subordinate groups (Plehwe and Walpen 2006: 27-45). But are these ideas politically neutral and universal? Not everyone agrees.

According most of all to a neo-gramscian view, the European Union has been a political milieu in which the rising transnational capitalist class composed most of all by finance capital and some other industrial transnational actors - has increased its control on the political and economic overall governance (Van Apeldoorn 2001). It is not by chance that the Treaties seem to 
be written to meet the interests of economic and financial elites: as we have seen, much of the power is concentrated in the hands of an oligarchy that puts together fractions of the dominant economic classes, with their political and cultural allies, and the market forces are able to influence the actions of national governments (see also Gallino 2015: 84-89).

For many scholars, with the support of political institutions this transnational network of market forces established an economic order suitable for their interests, developing a hegemonic project that looks for the consent of different social forces, attracting a broader array of interests and identities ${ }^{1}$. Thus, the political power of experts, technocrats, financial managers, bankers, economists and intellectual elites governing through technicalities - economic, administrative, judicial and so on - is the guarantee that particular interests are taken into the right account (Gill 1990, 1992, Overbeek and Van der Pij1 1993, Van der Pijl 1998, Robinson and Harris 2000, Carrol and Carson 2006, Weller and Singleton 2006).

And their public statements, which are based on theoretical assumptions derived from their neoliberal paradigm, have the dual effect of strengthening this paradigm and becoming a useful means to attempt to build consent and common sense.

\section{Neoliberal Discourse in Contemporary Italy: The Jobs Act (2014-15) and the Pensions Reform (2011)}

The Jobs Act is a comprehensive reform of labour, and of employment law, which takes place in Italy between 2014 and 2015 during Matteo Renzi's government. The core of the reform is law n. 183, approved on December $10^{\text {th }}$, 2014. The declared aim of the Jobs Act, implementing the actions by the previous government, is to create stable employment by facilitating the labour market. The law, which provides for a re-arrangement of organizational models in companies to set flexible schedules and tasks, also establishes incentives to companies that hire for an indefinite period - but dismissals are easier - and some measures to support the unemployed. The idea, repeatedly reaffirmed by Prime Minister Renzi in the previous months, is that reforms must encourage investment. Companies' investment in a free market, liberalization of dismissals and competitiveness seem to be the keywords.

The pensions reform, prepared by Elsa Fornero, Minister of Labour and Social Policies of Mario Monti's government, was instead part of the Decree Law of $6^{\text {th }}$ December 2011, called "Save Italy", converted in law on December $22^{\text {nd }}$. It is worth noting that Monti's government was established on November $16^{\text {th }}, 2011$ to face, with the approval of the Troika, the period of economic crisis marked by emergency - at least marked by the narratives of emergency. Considering the composition of the government (most of the ministers are from

\footnotetext{
${ }^{1}$ The bloc comprises small investors, professionals, privileged workers, states apparatus, etc., also if their status could be considered peripheral. The struggle to build a common sense is obviously broader and aims to obtain the consent of all the subordinate classes.
} 
university world, banking, finance - often simultaneously representatives of all these realms), this governmental experience seems to correspond to a perfect union of the projects and ideas of the European technocracy, of the financial interests and of the neoliberal thought.

The pensions reform, more specifically, was a measure, supported by the European Union, which aimed to reduce public spending related to pensions to cope with the financial crisis. The pension system is linked to a balanced budget of the State, in an overall legislative project aimed to include the requisite of a balanced budget in the Constitution, according to the principle of the sustainability of the public debt.

In both cases, an evaluation of the public statements of the members of the governments and of the international institutions that have supported and required these reforms, allows us to see, more than a simple response to the social and economic crisis, a specific way to represent the social question and the intervention of the State. This means, between the lines, the assertion of a highly ideological public discourse which tends to affect common sense, the taken for granted in the political and conceptual arena. Most of all because the media widely spread these statements and the implicit meanings they hold.

\section{Methodology}

According to the theoretical framework above developed, the public statements of political and economic elites bring into play the ideas of the neoliberal paradigm.

To support this hypothesis and further understand and identify the characteristics of this relation, as mentioned before, a study of official statements of members of the Italian government and European political or economic elites has been carried out. These statements have been collected from official documents - official letters, government programs - and Italian press - newspaper articles generally reporting press conferences or official interviews - and classified according to the reform they deal with: statements related to the pensions reform (52, from November 2011 to February 2012) and statements related to the Jobs Act (59, from October 2014 to January 2015). Next, the documents and the articles have been examined using a hermeneutic approach consisting in analysing and interpreting written texts (Montesperelli 2014, Kuckartz 2014) through an in-depth investigation of meanings. According to this approach, more than the single word it has been important to pay attention to the whole text (Kuckartz 2014) in order to recognize systems of meaning appearing in the communication.

The level of meaning and reference characterizing these statements is fundamental to understand how the discourse is affected by ideology and how it may, at the same time, reproduce and convey ideology ${ }^{2}$.

\footnotetext{
${ }^{2}$ Of course, it was important to be aware of the prevailing meanings and ideas of the neoliberal paradigm.
} 
The research process has focused on the identification of key concepts and themes emerging through a detailed examination of the texts and also taking account of the theoretical framework on the topic. Their analysis has allowed me to define common features, possible differences and specificities of the documents, reconstructing, in this way, values, ideas, beliefs, representations, motivations, and strategies underpinning the discourse expressed by the two laws.

At the same time, the study, by interpreting the discourse semantics, enabled me to recognize implications and presuppositions within the statements, i.e. possible latent meanings not explicitly expressed that could play essential ideological functions in discourse (Van Dijk 1995) ${ }^{3}$.

\section{Findings}

In this subsection, the main results of the hermeneutical study will be presented in order to define some characteristics of the speakers' opinions and their discursive strategies. In particular, for practical and expositive reasons, they will focus on the analysis on some specific statements excerpts.

The discourse surrounding the Jobs Act implies that the market is a fact of nature and has its unchangeable flow. The discourse has significant implications on the definition of what is the core problem of the crisis and what are the solutions. There is a significant paradigm change. According to this view the market is suffering from unemployment and excessive social spending, causing inflation and removing useful means for investments and to create jobs, growth and competitiveness. The social protection is seen as one of the strictest obstacles affecting the labour market and the economic development, not a measure to protect people (see van Apeldoorn 2001: 8388).

Cutting public spending to reduce the cost of labour for companies is the fundamental principle supporting Renzi's government political project. On the discursive level, the path leading to the Jobs Act in the previous months is very intense. For example, in October 2014, the Minister of Labour Giuliano Poletti reaffirms the need for the amendment of Article 18, the law on the reinstatement of dismissed workers, that will be replaced by monetary compensation, except in cases of discriminatory dismissals ${ }^{4}$. The economic reasons considered legitimate for the dismissal are included in the general expression "market difficulties", and for this much attention must be given. Not only because it is not clear if the problems of the companies must be taken into account, or the ones of the whole corresponding segments of economy, but for the implicit rhetoric that the market cannot be regulated and its free growth must be sustained.

\footnotetext{
${ }^{3}$ This means to find a way to understand the ideological foundations of the speaker's statements.

${ }^{4}$ Source: La Repubblica, 9 October 2014.
} 
Renzi himself, when dealing with the protection of workers in case of dismissal, does not hesitate to describe Article 18 as an obstacle for investment and economic recovery ${ }^{5}$. The concepts of competitiveness, free market, liberalization of the labour market are not called into question. The basic idea is that only following the laws of the market, stimulating the economic growth - that is reducing labour costs and increasing its elasticity - the crisis can be overcome and new labour will be created. The competitiveness of the companies is socially desirable because it should improve employment rates, even if labour is less protected and subjected to harsh conditions, and if participating in the labour market can be in contradiction with the quality of labour. The advertised aim is reducing unemployment, while the condition of labour and the so-called "working poors" are discursively concealed.

Not surprisingly, always in October 2014, Vitor Gaspar, Director of the Fiscal Affairs Department of the International Monetary Fund, and Kenneth Kang, Deputy Division Chief of the IMF, stresses the need for Italy for a structural reform involving public administration, justice, labour markets and privatizations. The basic idea is: public spending cuts (spending review), investments for companies, labour reform to convince companies to invest in workers and "to close the gap between protected and unprotected workers", fiscal and budget policies to support structural reforms ${ }^{6}$. The idea that tax cuts for companies is fundamental for the growth is a central point in the public discourse, as evidenced by an interview with Yoram Gutgeld, Renzi's economic councillor ${ }^{7}$.

The workers' protection seems just rhetorical. Tax cuts and the labour reform should encourage companies, but - most of all - budget policies should ensure transnational financial investors about the risk of default. The possible growth should improve employment, at least ideally, but also making easier to dismiss workers, even if measures to assist the unemployed and the dismissed are planned in the Jobs Act.

The rationale of the measure of the Jobs Act, that can be read on the official web pages of government ${ }^{8}$, will be, in fact, favouring the contract for an indefinite period of time, the so called "a tutele crescenti" ("through increasing protections") contract - which means, simply, a new regime of sanctions, mostly monetary, in case of unfair dismissal, which comprises higher refunds based on the seniority of the employee. Not surprisingly, the document explains that

"There are new, clearer and certain rules for unfair dismissals. The workers in this case will be guaranteed by economic refunds proportionate to their length of service. Discriminatory or manifestly instrumental

\footnotetext{
5 "Jobs Act, Renzi agli imprenditori:'Articolo 18 non sarà più ostacolo, ora possibile investire"', La Repubblica, 21 November 2014.

6 "Fmi 'L'Italia non ha un futuro radioso. Ue valuti di far sforare i conti a chi fa le riforme'", La Repubblica, 8 October 2014.

7 "Gutgeld: 'L’Italia ha una bomba atomica per la ripresa'", La Repubblica, 6 November 2014.

${ }^{8}$ http://bit.ly/1QTnkfS.
} 
employers' behaviour will be sanctioned with the employee's reinstatement."

The idea suggested is, once again, that the employment tax cuts and growth go hand in hand, and that they are the only ways to reduce unemployment, especially among young people. Most of all if justice for disputes on contracts of employment is rapid and credit and investment are encouraged ${ }^{9}$.

On November $21^{\text {st }}$, 2014, Italian Minister of Economy and Finance, Pier Carlo Padoan, writes a letter-document to Valdis Dombrovskis, Vice-President of the European Commission, and Pierre Moscovici, Commissioner of the European Commission, before the examination and discussion of the Draft Budgetary Plan by the EU. The goal is to attain encouragement and support for the reforms and more flexibility about the deficit policies. It remains, hidden in the words, the adoption of the neoliberal paradigm.

This letter follows that one, written on October $27^{\text {th }}$, to Jyrki Katainen, Vice-President and European Commissioner for Economic and Monetary Affairs and the Euro of the European Commission, where Padoan proposes, to face the recession and the risk of deflation and stagnation, the debt and deficit containing measures that will come (even at the expense of lower taxes). Here growth, debt problems, uncontrollable market conditions, adjustment of labour market, and public expenditure problems for economic growth are the key themes and the main concern.

Thus, Padoan's words are: "growth-friendly fiscal adjustment", "growthenhancing spending", "enhanced efficiency and quality of public expenditure", "further adjustments in the labour market and the civil justice", "the general government debt is on a sufficiently downward path", "to fully achieve the programmed effects on the debt" in spite of "adverse market conditions".

The November $21^{\text {st }}$ document is also more explicit, and it is worth of broad attention:

"The Italian Government is firmly committed to address the deeply rooted structural weaknesses of the economy and is currently engaged in the implementation of an ambitious and wide-ranging reform agenda aimed at providing the country with the institutional set-up, the rules and the incentives most appropriate to boost growth, competitiveness and employment."

Over recent months, the Government has introduced interrelated packages of structural reforms. More reforms are under way. They focus on job creation, improving competitiveness, strengthening growth and, therefore, fostering debt sustainability. Policy action includes:

reform of the labour market - Jobs act; measures to improve the efficiency of the public administration; reform of the civil justice system, as well as

\footnotetext{
9 This was also he opinion of Christine Lagarde, Managing Director of the IMF, who emphasized the good active policies on the labour market that "helps unemployed to receive training and assistance in finding employment he needs". La Repubblica, 9 December 2014.
} 
the reinforcement of the anti-corruption authority; deregulation of credit and improved access to capital markets that will increase financing alternatives for businesses, especially small and medium-size firms; simplification of the tax system, shifting the tax burden from productive factors and strengthening the fight against tax evasion; reform of the educational system to ultimately improve the quality of human capital.

In particular, the Jobs Act will allow far a more rapid response in adjusting production to cyclical and structural changes, with beneficial effects on investment and participation in the labour market, and a related reduction in the segmentation of the work force. By increasing employment, it will also faster the long term sustainability of the pension system, which is already one of the most solid thanks to past reforms. The Jobs Act is recognized by international organizations as a welcome step to put Italy on a more dynamic growth path.

(...)

Fiscal sustainability remains a key pillar of the reform agenda. Reducing the burden of public debt and freeing up resources far more productive uses is indeed essential far a balanced and equitable growth pattern. (...)"

The document, like the previous one, is a compendium of neoliberal ideas. The growth and market must be stimulated for employment and for the sustainability of the pension system. As rooted in common sense, the State cannot afford the pension system without a reform of labour. Political choices are presented as the answer to unchangeable conditions of natural economic processes. At the same time, in the document, the central problem of the State is the debt and deficit sustainability.

On the discursive level the budget sustainability can seem in contradiction to the measures to increase employment, involving massive public spending. The discourse, however, is able to shift attention to the skills and choices of the workers. In an individualized world, everyone has to choose and rationally control his life plans. Government should only increase the individual's ability to adapt to the market and its variability. This is the rationale of the watchword of the Jobs Act, the so-called "flexicurity". We can read on the government official web page an explanation of this rationale and of the consequent measures:

"The flexicurity model inaugurated by the Jobs Act is based on a balance between passive policies of income support and active policies. These policies improve the actual new placement of the worker, through personalized paths useful to the acquisition of new skills. The Employment Services, coordinated by the new National Agency for Active Work Policies, are enhanced to create efficient synergies and improve the match between demand and supply of labour. The Centers for Employment will stipulate with the user a Customized Service Agreement that will indicate the specific measures to promote the integration and reintegration into labour market. The new placement voucher represents an experiment for 
public and private sectors to provide a concrete answer to the citizen. For the first time, in all the regions and autonomous provinces, it is introduced a subjective right of the unemployed to have an endowment to spend to get a specialized and intensive support in the search for a new job, and we count on this aspect in a concrete and innovative way."

As we can see, the State aim is to provide the tools to improve workers' adaptation in a changing economy more than social protection. Unemployment is seen as lack of appropriate skills more than lack of job, and it is relevant to distribute equal opportunities only for worthy and motivated workers more than equal resources indiscriminately for all. Thus, the State activation must shape and train mobile workers able to change skills and jobs, to be flexible, adaptable, enterprising, autonomous, responsible, creative and capable of grasping the opportunities of the market. The State duty is helping the worker to be fit for the market more than regulating the market itself (see Serrano Pascual 2004). Now it is the responsibility of the worker to be adequate and deserve his job opportunities. Table 1 summarizes the main concepts and meanings that emerge by the analysis on the Jobs Act.

Table 1. Key Concepts of the Discourse Related to the Jobs Act

\begin{tabular}{|c|c|}
\hline Market & $\begin{array}{l}\text { - It is a fact of nature; } \\
\text { - It is uncontrollable; } \\
\text { - Its laws are unquestionable and functional; } \\
\text { - It requires liberalization and competitiveness to } \\
\text { face the crisis. }\end{array}$ \\
\hline Growth & $\begin{array}{l}\text { - It is crucial to overcome the crisis; } \\
\text { - It is based on policies able to induce companies } \\
\text { to invest and attractive in the eyes of markets } \\
\text { actors or investors; } \\
\text { - It is sustained by: spending cuts, investments for } \\
\text { companies, labour reform. }\end{array}$ \\
\hline $\begin{array}{l}\text { Obstacles to market, } \\
\text { growth and } \\
\text { competitiveness }\end{array}$ & $\begin{array}{l}\text { - Protection of workers, cost of labour, excessive } \\
\text { social spending, unemployment, debt. }\end{array}$ \\
\hline Main social conflict & $\begin{array}{l}\text { - The gap between protected and unprotected } \\
\text { workers. }\end{array}$ \\
\hline Social protection & $\begin{array}{l}\text { - Employment rates more than the quality of } \\
\text { labour. }\end{array}$ \\
\hline Unemployment & $\begin{array}{l}\text { Lack of appropriate skills more than lack of job; } \\
\text { - The duty of the State is to help the worker to } \\
\text { acquire new skills; } \\
\text { - Individual adaptation of the worker more than } \\
\text { regulation of the market; } \\
\text { The worker must be responsible, flexible, fit for } \\
\text { the market and its opportunities. }\end{array}$ \\
\hline
\end{tabular}


Going to examine the public statements of Monti's government, in the period of the so called "Save Italy", we will see that things are similar - here only a few selected examples will be presented, especially Minister Fornero's statements.

In a public report ${ }^{10}$, on December $3^{\text {rd }} 2011$, government demands a collective effort for the salvation and recovery of Italy. Presenting a structural reform of the national economy in a time of emergency, the statement talks about "urgent measures to ensure financial stability, growth and equity. The urgent action was necessary to deal with a severe financial crisis that hit in those weeks in the euro area and specifically the sovereign debt, also Italian". Growth, measures for the economic system and labour are the keywords.

During her first public speech, at the assembly of the National Craftsmanship Confederation, on November $23^{\text {rd }}, 2011$, Minister Fornero announces that the pensions reform is ready, recommending it as a useful measure to deal with the crisis. More than anything, however, she points out the basic principles guiding the actions of government, "financial rigour, impartial measures and growth". Rigour means "a different culture of the relationship between individuals and public spending, an element to reach also through educational action. The rigour, therefore, must be associated with a lifestyle always marked by sobriety". Growth instead implies "the removal and mitigation of all those traps and snares that have mortified growth and opportunities of this country ${ }^{11 " .}$

Fornero's plan has always been to combine "sustainability" and "equality"12. When she says "equality" she means balance between what she calls the "defenceless"- young workers - and the "saved" - the categories of the aged, more secure, worker that, going into early retirement, would enjoy special benefits. Simply, in reality it means more sacrifices for everybody.

The newspaper La Repubblica on November $26^{\text {th }}$ republishes a letter that Fornero wrote a few days before becoming Minister, where she basically outlines some guiding principles of the forthcoming government rationale ${ }^{13}$. The Minister stresses the need to switch to a completely contributory pension system and to extend the retirement age. All this to avoid what she considers the privileges of those who retire under the previous system, the salary pension scheme, that assures benefits

"too generous, that is higher than financial sustainability, resulting in a systematic violation of the criterion of sustainability and the principle of fairness between generations. (...) If the system is too generous to current generations, it builds an implicit debt that will fall on the young generation and the future ones."

\footnotetext{
${ }^{10}$ Source: La Repubblica, 4 December 2011.

11 "Crescita e pensioni, la Fornero si presenta. 'Riforma già fatta, serve equità sui sacrifici'", La Repubblica, 24 November 2011.

12 "Elsa Fornero, la superesperta che vuole riformare le pensioni", Corriere della Sera, 17 November 2011.

13 "Nuove pensioni di anzianitàișeplila riforma secondo la Fornero", La Repubblica, 26 November 2011.
} 
Fornero does not hesitate to speak of a "gift" in reference to the remuneration of those who enjoy the salary pension scheme, a gift - in particular - from the younger to the older generations. So that she outlines the possibility to measure the extent of the gift and generosity that the retired people enjoy, through an "indicator of the generosity of the pension systems", called Present Value Ratio (PVR).

One of the most substantial points is the strong saving and the "financial sustainability of the whole system". A reason to explicitly ask everyone the sacrifices implied by such severe measures ${ }^{14}$.

Fornero's idea, which is discussed in the first part of the letter, is also to create a sustainable system that helps an individual's existence planning. Her words are the following:

"when it comes to pensions it is in fact necessary to embrace the long term. The social security rules directly or indirectly influence many of the key decisions that individuals make in their lifetime, starting from a young age: how long to study, what profession to undertake, how to consume or save, when to retire from work.

If the rules are constantly changing, it becomes difficult to make reasoned plans for the future with clear implications both on the quality of life of individual citizens and on the growth of the economic system as a whole. If you want the rules to be shared - and not only suffered - these should be impartial: it must be ensured equal treatment to individuals; privileges be abolished. If you are planning a redistribution of resources, this must be transparent, from the richest to the poorest, and not vice versa."

The statements that we have examined give evidence to the kind of beliefs and the taken for granted that they want to inspire, as well as the adherence to the typical neoliberal thought. It is believed that competitiveness produces directly growth and employment, but, above all, austerity is proposed as the very political project. Also because, in this typical neoliberal view, social protection and social services are considered no more economically sustainable. This is why Fornero can blatantly talk about "gift" and "generosity" and ask for sacrifices. Finally, as in the case of the Jobs Act, Fornero underlines the individual responsibility of life projects and the auxiliary role of the State, which simply tries to provide the means to manage the risks.

Table 2 summarizes the main concepts and meanings emerging by the analysis on the pensions reform.

\footnotetext{
${ }^{14}$ Fornero employs the astute rhetoric to associate this call to hard sacrifices for everyone even the weak - with a vague intention to reduce the privileges of the wealthy and political classes (a generally unloved category).
} 
Table 2. Key Concepts of the Discourse Related to the Pensions Reform

\begin{tabular}{|c|c|}
\hline Growth & $\begin{array}{l}\text { - It is related to competitiveness and employment; } \\
\text { - It is essential to cope with the crisis; } \\
\text { - It is linked to financial rigour and austerity; } \\
\text { - It is linked to spending cuts, labour and pensions } \\
\text { reform - to remove obstacles and provide new } \\
\text { opportunities. }\end{array}$ \\
\hline $\begin{array}{l}\text { Stability and } \\
\text { sustainability }\end{array}$ & $\begin{array}{l}\text { They are crucial for growth and general wellbeing; } \\
\text { - They are fundamental to face two central problems of } \\
\text { the State: debit and deficit; } \\
\text { - They are linked to rigour and austerity - to cope with } \\
\text { the excessive public spending; } \\
\text { - They are important to ensure fair treatment of the } \\
\text { different generations. }\end{array}$ \\
\hline $\begin{array}{l}\text { Pensions system and } \\
\text { social services }\end{array}$ & $\begin{array}{l}\text { - They are too expensive for the State Budget and the } \\
\text { main causes of crisis and debt. }\end{array}$ \\
\hline Rigour & $\begin{array}{l}\text { - It is associated with incontrovertible spending cuts; } \\
\text { - It is a cultural responsibility for individuals; } \\
\text { - It is linked to an individual moderate lifestyle; } \\
\text { - It means sacrifices for everyone. }\end{array}$ \\
\hline Equality & $\begin{array}{l}\text { - It is between young and aged (protected) workers, } \\
\text { more than among social classes; } \\
\text { - It implies that the salary pension scheme - a public } \\
\text { service - is a too generous "gift". }\end{array}$ \\
\hline
\end{tabular}

\section{Discussion and Conclusions: a Discursive Hegemonic Struggle}

The public statements of the members of the two Italian governments ${ }^{15}$ and of international, evidently neoliberal, institutions who supported or lobbied for the adoption of specific economic measures ${ }^{16}$ - and their official documents or communication are part of a discursive struggle.

The implicit attempt of this rhetoric, in addition to legitimise the economic policies of the two governments, is to divulge a representation of the economic crisis and its solutions that is in tune with the neoliberal doctrines. Thus, this discursive struggle can be considered a hegemonic attempt because it is based primarily on the building of consent and universal ideas about the general interest and the priorities for action. It means, ultimately, to build what is taken for granted.

For example, the public interest could be employment, for sure, but you cannot raise doubts concerning the freedom of markets, and the natural relationship among growth, competitiveness and employment. Globalization and market are, according to this rationale, not only irreversible and not controllable, but potentially more profitable (Van Apeldoorn 2001, Palley 2005).

\footnotetext{
${ }^{15}$ Renzi's and Monti's.

${ }^{16}$ A dialogue, anyway, with some superficial disagreements.
} 
Furthermore, as we have seen, the discourse is focused on other specific assumptions: market, that is a matter of fact, is suffering from unemployment, protection of workers and excessive social spending; the debt and deficit sustainability is the main problem; the pension system and the social services are too expensive for the State budget and they are the main causes of the debt and of the crisis - therefore, austerity is just an inevitable consequence; the tax cuts and the labour reform encourage the companies to invest and are crucial for growth; unemployment means lack of skills more than lack of job (see also Shaikh 2005: 41-49).

The pervasiveness of this discourse, in Italy as in other Southern European countries, which have been the most affected by the crisis, highlights the strength of an ideology developed most of all from the 70s onwards to revitalize the economy, and that still claims that "there is no alternative". Furthermore, it gives us an interesting observation point to examine the relationship between economic measures and power within European integration $^{17}$.

These assumptions, conveyed by neoliberal discourse, aim to be incorporated in general common sense. And, actually, all this remains a widespread thought. But this taken for granted view hides potential different positions - which are less... taken for granted.

For example, focusing on the notion that public spending has aggravated the national budget can conceal the weight of financial obligations, of the rescue of the banks and of the tax benefits granted to companies and wealthy taxpayers. And the notion of debt sustainability, a true neoliberal diktat, behind the rhetorical image of the mother making ends meet - easily incorporated in the common sense - benefits the investments of transnational financial capital that fears the State default. Thus, the budget policies ensure, most of all, market actors and bondholders - especially banks and other financial investors - about the risk of default (Gill 2001).

At the same time, for Luciano Gallino (2015) the inextricable link among the reform of labour, growth and pension system sustainability can be arbitrary, since the State can prioritize public services or pensions, and in Italy it is not true that the pension system for employees is an unbearable burden for the State. Gallino stresses also that even the correlation between labour flexibility and employment increase has never been really proven (Gallino 2013: 157158; See also Saad-Filho 2005) ${ }^{18}$.

Thus, the idea that political choices just react to the inflexible conditions of market makes us forget that the State chooses how to distribute resources and to face inequalities ${ }^{19}$.

\footnotetext{
${ }^{17}$ However, if in the early years of the crisis the governments were more inclined to implement the measures requested by Europe, and its rhetoric, in the last years the relation is more confrontational, despite the search for compromise.

${ }^{18}$ Even The Organisation for Economic Co-operation and Development has recognised that this correlation is not verified.

${ }^{19}$ For many scholars, also the belief in automatic positive effects of free trade on growth and poverty reduction is empirically weak (Deraniyagala 2005: 99-105).
} 
Furthermore, the severest cost of austerity, pillar of the neoliberal ideology, is mainly on younger and less skilled workers shoulders. Those that the neoliberal discursive struggle would like to oppose to workers with greater protections - more than to the international financial capital. But focusing on equity between young and old workers, or between unprotected and protected employees, means to hide the greatest inequality, the one between dominant and subordinate classes. One consequence of this idea is the potential corrosion of social solidarity and the increase of individual and collective insecurity, despite the stated intentions.

As we have seen, the Jobs Act and the Fornero's reform underline another neoliberal notion: the individual responsibility of life projects and the auxiliary role of the State, which simply tries to provide the means to manage the risks. However, it could be said, the State duty should be creating jobs through macroeconomic policies more than helping workers to be fit for market (Serrano Pascual 2004). But the idea of free and responsible individual making his choices and realizing his/her potential can ideologically justify economic inequalities and, therefore, their incongruence with the neoliberal promises.

The discursive effort of governments and experts - that I have examined aims to spread an interpretation of social and economic reality, and the definition of priorities and public interest. The economic measures and the public discourse legitimising them are in correspondence to the neoliberal doctrines that, in the last decades, seemed an instrument for transnational capitalist and financial classes to regain power and increase inequality (Duménil and Lévy 2005: 13-17, Gallino 2012: 123-148, 2013: 257-268). The views and the interests of the subordinate classes are moderately taken into consideration, through welfare provisions maintained in the last years, for example, but the priority remains the preservation of a typically neoliberal economic system, whose enemies are inflation, workers' interests, the obstacles to free trade and finance system, etc.

Interestingly, Stephen Gill (2001: 59) stresses that market operators and international financial institutions supervise European government policies, and discursively it is important for them to suggest that the orthodox neoliberal measures provide "greater economic prosperity for all".

But focusing on a specific version of general prosperity, keeping in the background different ideas, is a radical means of power. However, it is important, in conclusion, to point out that, although we speak of hegemonic project, dissenting strategies can emerge and fight. And voices of dissent exist - otherwise it would not be a discursive struggle, and, anyway, the social world is always based on the conflict between divergent forces and interests. But these voices have to know how to prepare, in turn, a concrete counterideological project, if they want to be effective actors of political contention and of a change. 


\section{Acknowledgments}

I wish to thank Domenico Maddaloni and Maria Carmela Catone Università degli Studi di Salerno, Italy - for their comments and suggestions.

\section{References}

Bieler A (2001) Questioning cognitivism and constructivism in IR Theory: reflections on the material structure of ideas. Politics 21(2).

Carroll W, Carson C (2006) Neoliberalism, capitalist class formation and the global network of corporations and policy groups. In D Plehwe, B Walpen, G Neunhöffer (Eds) Neoliberal Hegemony. A Global Critique. London and New York: Routledge.

Collins R (1992) Sociological insight. An introduction to non-obvious sociology, $2^{\text {nd }}$ edition. Oxford: Oxford University Press.

Cox RW (1987) Production, power and world order: social forces in the making of history. New York: Columbia University Press.

Cox RW (1983) Gramsci, hegemony, and international relations: An essay in method. Millennium: Journal of International Relations 12(2).

Cox RW (1981) Social forces, states, and world orders: beyond international relations theory. Millennium: Journal of International Relations 10(2).

Deraniyagala S (2005) Neoliberalism in international trade. sound economics or a question of faith? In A Saad-Filho, D Johnston (Eds) Neoliberalism. A Critical Reader. London: Pluto Press.

Duménil G, Lévy D (2005) The neoliberal (counter-) revolution. In A Saad-Filho, D Johnston (Eds), Neoliberalism. A Critical Reader. London: Pluto Press.

Gallino L (2015) Il denaro, il debito e la doppia crisi spiegati ai nostri nipoti [The money, the debt and the double crisis explained to our grandchildren]. Torino: Einaudi.

Gallino L (2013) Il colpo di stato di banche e governi. L'attacco alla democrazia in Europa [The coup of banks and governments. The attack on democracy in Europe]. Torino: Einaudi.

Gallino L (2012) La lotta di classe dopo la lotta di classe [The class struggle after the class struggle]. Roma-Bari: Laterza.

Gill S (2001) Constitutionalising capital: EMU and disciplinary neo-liberalism. In A Bieler, AD Morton (Eds) Social Forces in the Making of the New Europe- The Restructuring of European Social Relations in the Global Political Economy. Houndmills, Basingstoke, Hampshire: Palgrave.

Gill S (1992) Economic globalization and the internationalization of authority: limits and contradictions. Geoforum 23(3).

Gill S (1990) American hegemony and the trilateral commission. Cambridge: Cambridge University Press.

Gill S, Law D (1998) The global political economy: perspectives, problems and policies. Brighton: Johns Hopkins University Press.

Gramsci A (1975) Quaderni dal carcere [Prison Notebooks]. Torino: Einaudi.

Harvey D (2005) A brief history of Neoliberalism. Oxford: Oxford University Press.

Kuckartz U (2014) Qualitative text analysis: A guide to methods, practice and using software. London: Sage.

Lukes S (2005) Power. A radical view, $2^{\text {nd }}$ edition. Houndmills, Basingstoke, Hampshire: Palgrave Macmillan. 
Montesperelli P (2014) Comunicare e interpretare. Introduzione all'ermeneutica nella ricerca sociale [Communicating and Interpreting. Introduction to hermeneutics in social research]. Milano: EGEA.

Overbeek H (2004) Transnational class formation and concepts of control: towards a genealogy of Amsterdam Project in international political economy. Journal of International Relations and Development 7.

Overbeek H, Van der Pijl K (1993) Restructuring capital and restructuring hegemony: neo-liberalism and the unmaking of post-war order. In H Overbeek (Ed) Restructuring Hegemony in the Global Political Economy. The Rise of Transnational Neo-Liberalism in the 1980s. London: Routledge.

Palley T (2005) From Keynesianism to Neoliberalism. Shifting paradigms in economics. In Saad-Filho A, Johnston D (Eds). Neoliberalism. A Critical Reader. London: Pluto Press.

Plehwe D, Walpen B (2006) Between network and complex organizatione: the making of neoliberal knowledge and hegemony. In D Plehwe, B Walpen, G Neunhöffer (Eds) Neoliberal Hegemony. A Global Critique. London and New York: Routledge.

Purvis T, Hunt A (1993) Discourse, ideology, discourse, ideology, discourse, ideology. The British Journal of Sociology 44(3).

Robinson W, Harris J (2000) Towards a global ruling class? Globalization and the transnational capitalist class. Science \& Society 64(1).

Saad-Filho A (2005) From Washington to post-Washington consensus: Neoliberal agendas for economic development. In A Saad-Filho, D Johnston (Eds) Neoliberalism. A Critical Reader. London: Pluto Press.

Serrano Pascual A (2004) Conclusions: toward convergence of the European activation policies? In Id. (Ed.). Are Activation Policies Converging in Europe? The European Employment Strategy for Young People. Brussels: ETUI.

Shaikh A (2005) The economic mythology of Neoliberalism. In A Saad-Filho, D Johnston (Eds) Neoliberalism. A Critical Reader. London: Pluto Press.

Tilly C (1991) Domination, resistance, compliance... discourse. Sociological Forum 6(3).

Van Apeldoorn B (2001) The struggle over European Order: transnational class agency in the making of "Embedded Neo-Liberalism". In A Bieler, AD Morton (Eds) Social Forces in the Making of the New Europe- The Restructuring of European Social Relations in the Global Political Economy. Houndmills, Basingstoke, Hampshire: Palgrave.

Van der Pijl K (1998) Transnational classes and international relations. London: Routledge.

Van der Pijl K (1989) Ruling classes, hegemony and the state system: theoretical and historical considerations. International Journal of Political Economy 19(3).

Van Dijk TA (1995) Discourse semantics and ideology. Discourse \& Society 6(2).

Weller C, Singleton L (2006) Peddling reform: the role of think tanks in shaping the neoliberal policy agenda for the World Bank and International Monetary Fund. In D Plehwe, B Walpen, G Neunhöffer (Eds) Neoliberal Hegemony. A Global Critique. London and New York: Routledge. 